\title{
A!
}

This is an electronic reprint of the original article.

This reprint may differ from the original in pagination and typographic detail.

Lu, Liangliang; Kujala, Pentti

\section{Economic and Financial Impacts of Oil Spills}

Published in:

Oil Spill Occurrence, Simulation, and Behavior

Published: 26/03/2021

Document Version

Peer reviewed version

Please cite the original version:

Lu, L., \& Kujala, P. (2021). Economic and Financial Impacts of Oil Spills. In Oil Spill Occurrence, Simulation, and Behavior CRC Press.

This material is protected by copyright and other intellectual property rights, and duplication or sale of all or part of any of the repository collections is not permitted, except that material may be duplicated by you for your research use or educational purposes in electronic or print form. You must obtain permission for any other use. Electronic or print copies may not be offered, whether for sale or otherwise to anyone who is not an authorised user. 


\author{
Book Title Oil Spill Occurrence, Behavior and Simulation \\ Chapter 8. Title Chapter 8. Economic and Financial Impacts of Oil Spills \\ Chapter Authors Liangliang Lu (https://orcid.org/0000-0002-2616-0438) \\ Pentti Kujala (https://orcid.org/0000-0003-2665-9957) \\ Aalto University \\ School of Engineering \\ Department of Mechanical Engineering \\ Marine Technology
}

\begin{abstract}
This chapter relates to the economic and financial impacts of oil spills and has three relevant sections. The first section describes the oil and gas industry system and identifies potential oil spills inside the system, as well as the response and recovery system after spills. The second section discusses the oil spill economic impacts and subdivisions, with focus on various estimation methods. The third section summarizes economic impacts for some major oil spill accidents by comparing compensations, claims and various estimated costs.
\end{abstract}




\section{Economic and Financial Impacts of Oil Spills}

This chapter describes the impacts of oil spills from the economic and financial perspectives. Before entering the topic of oil spill impacts, the definitions of the economics and finance will be introduced first so that the scope and perspective of analyzing the oil spill impact is clarified. Economics is understood as a social science which studies the production, consumption, and distribution of goods and services, with the aim of explaining how economies work and how their agents interact. Modern economics is in fact often very quantitative and heavily mathoriented in practice and divided into two branches: macroeconomics and microeconomics. Macroeconomics studies how the aggregate economy behaves, such as inflation, national income, gross domestic product (GDP) and changes in unemployment. Microeconomics is the study of economic tendencies, focusing on the smaller factors that affect choices made by individuals and companies.

Finance in many respects is an offshoot of economics and can be divided into three categories: public finance, corporate finance and personal finance. It describes the management, creation and study of money, banking, credit, investments, assets and liabilities that make up financial systems, as well as the study of those financial instruments.

Based on the understanding of the above described definitions of economics and finance, the analysis of the oil spill impact from economic and financial perspective then needs to go through the oil and oil spill system, which interact with the society. Therefore, the following section will first introduce the oil and oil spill response and recovery related system in Section 1 and the economic and financial impact of oil spill will then be introduced in section 2, based on the identified system in section 1. Major oil spill examples will be discussed in Section 3.

\section{Oil, oil spill, response and recovery system}

This section aims to introduce how and where the oil spills may happen and what are the corresponding response and recovery options. Firstly, the oil and gas system will be described 
so that we can know what the potential oil spill scenarios are and where they may happen. Secondly, Oil response and recovery system will be introduced briefly.

\subsection{Oil and gas system and potential oil spills}

Knowing the oil and gas industry system helps to understand where the oil spills may happen and their impacts inside and outside the system, which will facilitate the understanding on economic and fanatical aspects.

\subsubsection{Oil and gas system}

Oil and gas industry system are usually categorized into three sectors: upstream, midstream and downstream (Devold, 2013), as illustrated in Figure 8.1.

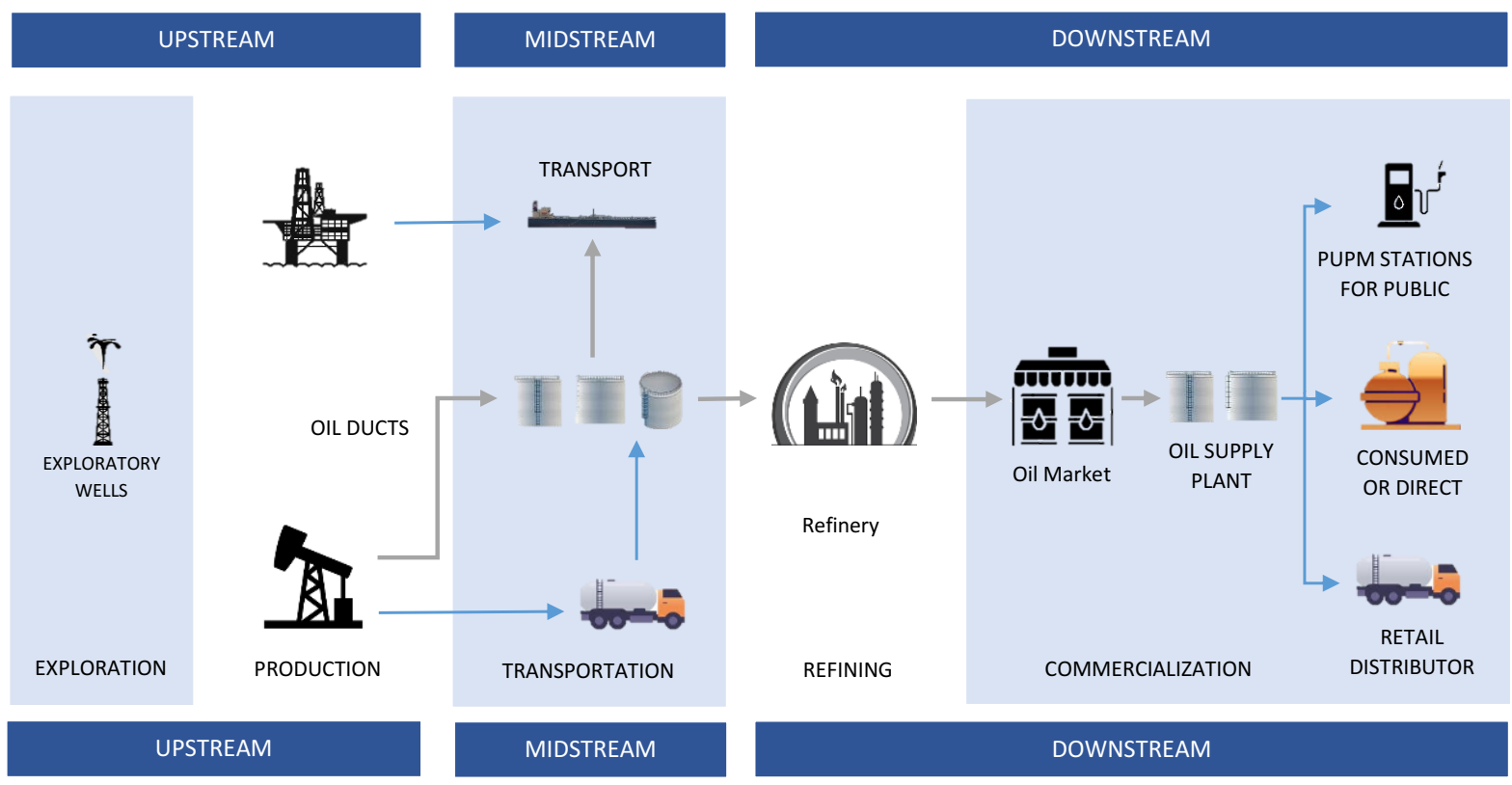

Figure 8.1 Oil and gas system diagram

The upstream sector is also known as the Exploration and Production (E\&P) sector. It is consisted of processes and operations that involve searching for potential underground or underwater crude oil and natural gas fields, drilling of exploratory wells, and subsequently drilling and operating the wells that recover and bring the crude oil and/or raw natural gas to the surface. This sector can be onshore or offshore. Offshore exploration and production involve exploration ships and different offshore platforms or floating production storage and offloading (FPSO) ship, floating liquefied natural gas (FLNG) ship, etc. facilities. 
The midstream sector includes the transport and storage of crude oil before refining and processing it into fuels and elements that have become indispensable in our day-to-day life. Transportation options can vary from small connector pipelines to massive cargo ships making trans-ocean crossings, depending on the commodity and distance covered. After being driven to the plant it is stored in large tanks.

The refining, commercialization and distribution of products derived from crude oil and natural gas constitutes the downstream sector. In the refineries, the crude undergoes a process of physical separation and then chemical processes to extract the different components that form it. The extracted derivate are fuels and petrochemicals. Thus, consumers receive products such as gasoline, kerosene, diesel, lubricants, asphalt, natural gas and liquefied gas, synthetic rubber, fertilizers, preservatives, packaging and plastics. Wholesale and retail marketing activities help move the finished products from energy companies to retailers or end users.

\subsubsection{Potential oil spills}

Understanding the oil system helps to see potential oil spills which may happen during the whole process. Table 8.1 lists the potential oil spill sources for different stages for onshore and offshore systems.

Table 8.1 Potential oil spill sources

\begin{tabular}{lll}
\hline & Onshore & Offshore \\
\hline Upstream & Well & Well \\
& Pipeline & Pipeline \\
& & Platform \\
& Ship \\
Midstream & Pipeline & Pipeline \\
& Truck/Train/Ship & Ship/Truck/Train \\
Storage & Storage \\
Downstream & Refiners & Refiners \\
& Oil \& gas station & Oil \& gas station \\
& Airplane & Airplane \\
& Ship & Ship \\
Car/bus/truck & Car/bus/truck \\
& & Wreck \\
\hline
\end{tabular}


In upstream stage, oil may be spilled from wells and pipelines during onshore and offshore activities. Comparing with onshore, offshore oil spill sources also includes platforms and ships (e.g. FPSO or FLNG). In midstream, the differences lie in the transportation. In addition to pipelines, ships are necessary to transport the drilled oil from offshore to shore. Onshore oils are supposed to transport by pipelines or onshore transportations. However, due to the global features of oil, oil refining facilities usually locate in different places. For example, the main onshore oil well may locate in Middle East, while the oil refining factories are in Europe and Asia. Therefore, even the onshore oils need ships for transportation, which makes little difference for onshore and offshore. In the downstream, oil spill sources from onshore and offshore have almost no difference. After the refining, oils will be distributed to different industries and customers. It can be inside cars, buses and oil gas stations in cities. It can also be in airplane or ships as fuel. The ships will be operated then for different purposes, including the operations in upstream and midstream. Meanwhile, there are some other sources, e.g. wrecks on the seabed which still contain oils. In addition, offshore oil spills may also happen in sea ice conditions, which gives more complex situations (Lu et al., 2019).

From the potential oil spill sources, the complexity and severity of oil spill can be assessed somehow. It can be seen offshore oil spills are usually more complex as the environment is more complicated and not easy to control. Meanwhile upstream usually has larger possibility to have bigger oil spills. Although oil spills in refiners and storage can also be large, the monitoring system and response system can be timely so that the consequence and severity is easy to control. While the offshore oil spills are usually difficult to control and it also takes long time to for response facilities to reach and conduct measures. Therefore, the focuses in this chapter are on the offshore oil spill cases, including upstream sources and the ships in other stages. Statistically, it can also be seen that major oil spill accidents are from offshore activities; see more examples in Section 3. 


\subsection{Oil spill response and recovery system}

This section aims to briefly describe the oil spill response and recovery system so that the relevant elements can clearly stand out in this period and this will be beneficial on communicating the economic and financial parts.

Tiered approach (IMO, 2010; EPPR, 2015) is developed and adopted for different oil spills. The approach has three tiers and can be described as follows:

Tier 1: Operational-type spills that may occur at or near a company's own facilities, as a consequence of its own activities. An individual company would typically provide resources to respond to this type of oil. Commercial ships are required to have a shipboard oil pollution emergency plan (SOPEP) to deal with Tier 1 level spills. Details of plan requirements vary with the nation involved.

Tier 2: A larger spill in the vicinity of a company's facilities where resources from other companies, industries and possibly government response agencies in the area can be mobilized on a mutual aid basis. The company may participate in a local co-operative where each member pools their Tier 1 resources and has access to equipment that may have been jointly purchased by a co-operative.

Tier 3: A large spill where substantial further resources may be required and support from a national or international co-operative stockpile may be necessary. It is likely that such operations would be subject to government controls and direction through a combined interagency/industry command center.

An effective response and recovery is to select and implement a combination of response techniques that would be most effective in minimizing overall short and long term impact, including preventing oil from reaching the shoreline and sensitive areas. The response countermeasures generally include three types: 1) mechanical containment and recovery by utilizing booms and skimmers, 2) a combination of strategies to concentrate the oil and burn in-situ; 3) dispersants that disperse surface oil into the water column as small oil droplets for 
microorganism to biodegrade effectively. All the responses options need ships to deploy booms to stop further oil spreading. In addition, relevant response ships equipped with inside skimmers system or mounted external skimmers are needed to conduct the recovery process if the mechanical recovery approach is adopted. In-situ burning and dispersants approaches requires environmental favor on the conditions, e.g. suitable oil film thickness, waves, winds, degree of emulsification, etc. The aerial application of proven herding agents and ignitors is another possible rapid tool. Dispersants are usually distributed by fast aircraft for large spills to improve the response time. In addition to the response countermeasures, detection, monitoring and tracking are important steps among the response actions. It is crucial to know where spilled oil is and the condition of that oil (degree of weathering) at any given time. Therefore, a mix of airborne sensors, remote sensing, including marine or satellite radar system, even trajectory analysis and transportation modelling may be applied. Unmanned Aerial System (UAS) and Autonomous Underwater Vehicles (AUVs) can also be helpful in some cases. When the spilled oil comes from the seabed well or subsea risers, Remote Operation Vehicles (ROVs) and other oil recovery equipment, e.g. containment dome, will also be used to control or stop the oil spill. In extreme cases, other drilling platforms may be required to make additional drill to permanently block the wells. Before the oil reaches to the shoreline, the protective booms are usually used to protect the coastal areas from the oil. After the oil reaches the shoreline, the shoreline oil recovery or remove becomes the priority by using machines and human labors.

\section{Economic and Financial aspects of oil spill}

After knowing the oil, oil spill, response and recovery system, the focus in this section moves to the economic and financial aspects of oil spill. The emphasis is still on the offshore oil spill cases. 
Figure 8.2 shows the diagram of oil spill impact framework (Chang et al., 2014). The impact of the oil spill can be described from short term and long term perspective, which link two main parts: ecology and society impacts. When oil spill happens, the spilled oil will be exposed to the external environment and the transportation and weathering start to happen with the interaction with the environmental conditions. Meanwhile, the corresponding response actions usually also begin to remove the oil and mitigate the oil spill impacts. Thus, the first economic impact is from the response actions which include various cooperation, equipment and resources deployments. The further weathered oil then begin to influence the ecosystem to the places it is transported. The regional ecosystem species, mobility and habitat will be affected and cause even damages in the long time. This leads to the natural resource damage. In addition, the impacted ecosystem will also influence the society and its economy through fisheries, tourism and recreation, etc. The socioeconomic impacts will interact regionally and even globally through the global economic and financial system and cause long time impacts. There are also social impacts on the human beings, e.g. health and physiological impacts and there will also be more research activities going on after the oil spills. All of these will give a further impact on the technology, regulations and marine activities, e.g. traffic volume, oil drilling, etc. 


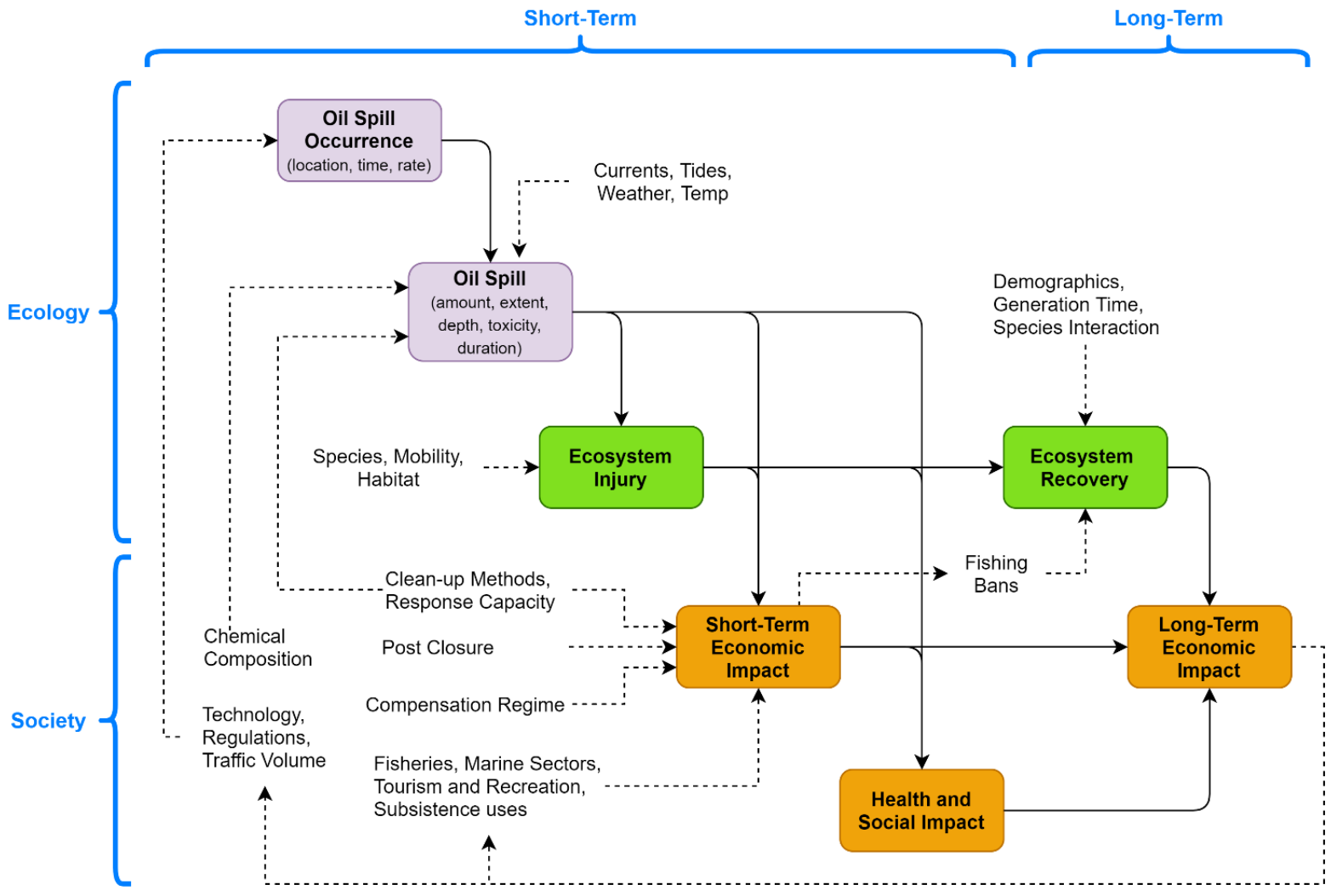

Figure 8.2 Oil spill impact framework. $($ Boxes $=$ outcomes, lowercase $=$ variables, solid lines $=$ linkages between oil spill occurrence and socioeconomic impacts, dotted lines $=$ linkages between exogenous variables and outcomes). (After Chang et al., 2014)

Based on the diagram of how an oil spill influence the ecology and society in Figure 8.2, the following sections are going to summarize an overall structure on the economic and financial impacts from an oil spill, as shown in Figure 8.3.

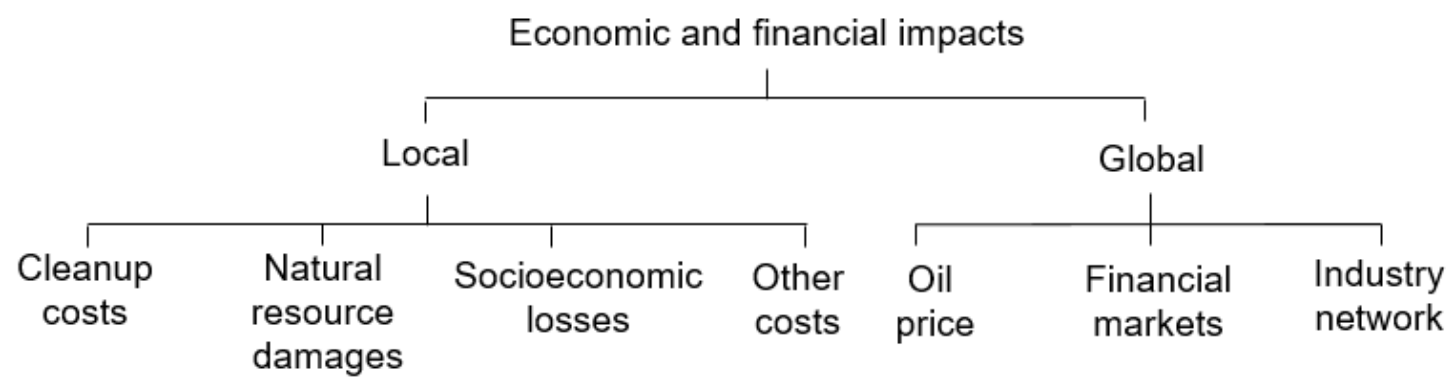

Figure 9.3 Economic impacts from oil spills

Firstly, the economic impact is divided as local and global impacts. Local impacts refer to the damage or costs to the regional environment and society. It includes cleanup costs, socioeconomic loss, natural resource dam and other costs. In the global aspect, the impact is 
transferred through global financial market and causes influence on the global society. The impact may be reflected by oil price, stock market, industry and regulations, which further influence the global economy and finance. This global impact exists mainly for the major oil spills. The local and global impacts will be discussed in following sections in detail.

\subsection{Local economic impact}

The local economic impact refers to the oil spill induced impacts related to the regional economic damage and loss, including cleanup costs, natural resource damage, socioeconomic loss and other costs in the oil spilled water and region. The loss and damages will influence the individuals and companies in a small scope and are also reflected in macro economy including inflation, regional or national income, gross domestic product (GDP) and changes in unemployment, etc. It is then a very complicated system to study. Therefore, the following sections will only restrict the target on the more straightforward impacts: the cleanup costs, natural resource damage, socioeconomic loss and other corresponding costs caused by oil spills, with focus on the estimation procedures and methods.

\subsubsection{Cleanup costs}

The cleanup of oil covers the removal of oil from the sea, coastal waters and shorelines as well as the disposal of the collected oil waste. It includes the command center coordinating cost, offshore oil treatment (mechanical recovery, dispersant spraying, or in-suit burning), nearshore recovery and protection, shoreline and wildlife cleanup, etc. Due to the complexity of the cleanup procedure and wide involvement of the various resources, there are several approaches to estimate the cleanup cost for an oil spill accident.

\subsubsection{Estimation model based on causation}

The first one is the estimation based on the causal cost components, more like direct estimation, which calculated the costs by adding each cost from various cost sources. The general equation can be expressed as:

$$
C_{c}=\sum_{t=1}^{n} C_{t}
$$


Where $C_{c}$ is the total cleanup cost, $C_{t}$ is the cost used for different type of resources, t means the resource category and $\mathrm{n}$ is the total number of the categories.

The general equation is simple, however more calculation and estimation efforts are needed for digging into the details in each cost category. The next sections will show two sample methods of the cleanup cost estimation.

\subsection{Oil spill cost study in UK}

A study on oil spill (Oil \& Gas UK and OPOL, 2012) was conducted to estimate the oil spill induced costs. Four spill scenarios were studied, as shown in Table 8.2. Oil transportation and weathering was firstly modelled by running the simulation model and then the oil distribution can be understood to further estimate the induced cleanup cost.

Table 8.2 Oi spill scenarios in the case study (Oil \& Gas UK and OPOL, 2012)

\begin{tabular}{ccccccc}
\hline Location & Lat/Lon & Oil type & $\begin{array}{c}\text { Release } \\
\text { duration } \\
\text { (days) }\end{array}$ & $\begin{array}{c}\text { Release } \\
\text { rate }\left(10^{3}\right. \\
\text { barrels } \\
\text { per day) }\end{array}$ & $\begin{array}{c}\text { model run } \\
\text { duration } \\
\text { (days) }\end{array}$ & $\begin{array}{c}\text { ITOPF } \\
\text { group } \\
\text { classification }\end{array}$ \\
\hline 1 & $\begin{array}{c}60^{\circ} 25^{\prime} \mathrm{N} / \\
4^{\circ} 6^{\prime} \mathrm{W} \\
58^{\circ} 5^{\prime} \mathrm{N} /\end{array}$ & Schiehallion & 10 & 31 & 10 & $\mathrm{G} 3$ \\
2 & $\begin{array}{c}1^{\circ} 42^{\prime} \mathrm{W} \\
61^{\circ} 35^{\prime} \mathrm{N} / \\
1^{\circ} 18^{\prime} \mathrm{E}\end{array}$ & Captain & 10 & 18 & 10 & $\mathrm{G} 3$ \\
$57^{\circ} 45^{\prime} \mathrm{N} /$ & Magnus & 10 & 58 & 10 & $\mathrm{G} 2$ \\
$0^{\circ} 54 \mathrm{E}$ & Forties & 10 & 41 & 10 & $\mathrm{G} 2$ \\
\hline
\end{tabular}

Direct cost estimation was applied by setting nine cost categories: 1) command center costs, 2) offshore dispersant spraying, 3) offshore mechanical recovery, 4) nearshore mechanical recovery, 5) protective nearshore booming, 6) shoreline cleanup, 7) wildlife cleanup costs, 8) shoreline cleanup assessment team (SCAT), media liaison and surveillance, 9) disposal costs. In each category, there are variable per day costs and fixed variable costs and all the detailed cost for each item are listed in each category, which allows the direct calculation of the cleanup cost by following equation:

$$
C_{t}=\sum_{i, j=1}^{p, q} C_{V i} N_{V i} T_{V i}+C_{F j} N_{F j}
$$


Where $C_{t}$ is the cleanup cost for category t, $C_{V i}$ is the cost per day for variable $\mathrm{i}$ in category $\mathrm{t}$, $N_{V i}$ is required number for variable $\mathrm{i}$ per day and $T_{V i}$ is the estimated days needed for conducting variable i activity. $C_{F j}$ is the fixed cost per unit for variable $\mathrm{j}, N_{V j}$ is required number for variable $\mathrm{j} . \mathrm{p}$ and $\mathrm{q}$ are the total number of the variable per day and fixed variables in each category.

The method here is simple and it can be calculated inside MS Excel by setting the equations. However, the emphasis in this example is the identified categories and the detailed cost information about each resource in the categories. Getting the right variable and cost information becomes essential in this kind of direct estimation. More information can be found in the report ((Oil \& Gas UK and OPOL, 2012)). It should be noted that the cost information can be just used for reference as the cost vary in different locations and different scenarios. Table 8.3 is the estimated costs.

Table 8.3 Estimated cleanup costs in the case study (Unit: million \$) ((Oil \& Gas UK and OPOL, 2012))

\begin{tabular}{ccccccccc}
\hline \multirow{2}{*}{ Remedial measures } & \multicolumn{2}{c}{ Location 1 } & \multicolumn{2}{c}{ Location 2 } & \multicolumn{2}{c}{ Location 3 } & \multicolumn{2}{c}{ Location 4 } \\
& Low & High & Low & High & Low & High & Low & High \\
\hline Shoreline cleanup & 25.6 & 88.0 & 30.4 & 104.0 & 5.1 & 17.6 & 1.8 & 5.9 \\
$\begin{array}{c}\text { Offshore mechanical } \\
\text { recovery }\end{array}$ & 20.8 & 20.8 & 20.8 & 20.8 & 20.8 & 20.8 & 20.8 & 20.8 \\
$\begin{array}{c}\text { Protective nearshore } \\
\text { booming }\end{array}$ & 24.0 & 24.0 & 22.4 & 22.4 & 30.4 & 30.4 & 30.4 & 30.4 \\
Command center & 13.9 & 13.9 & 20.8 & 20.8 & 30.4 & 30.4 & 30.4 & 30.4 \\
Media and SCAT & 8.5 & 8.5 & 8.5 & 8.5 & 8.5 & 8.5 & 8.5 & 8.4 \\
Wildlife response & 2.9 & 2.9 & 2.9 & 2.9 & 2.9 & 2.9 & 2.9 & 2.9 \\
$\quad$ Disposal & 2.1 & 2.1 & 2.1 & 2.1 & 3.2 & 3.2 & 3.2 & 3.2 \\
$\quad$ Total & 13.9 & 67.2 & 15.8 & 43.2 & 15.0 & 19.2 & 11.2 & 11.2 \\
\hline
\end{tabular}

\subsection{Cleanup cost study in Finland}

Another studies on the oil spill cleanup cost estimation were carried out in Finland (Montewka et al., 2013; Helle et al., 2015), which belong to the category of estimation based on causal cost components. The principles of the studies are adding up all costs for different resources. However, the difference is that the Bayesian Network method is applied, which leads to a 
probabilistic model. As shown in Figure 8.4, cleanup costs are divided into offshore and onshore and further broken down to detailed categories. The offshore costs include preparation costs, booms, combating cost, cost of emptying tanks and air surveillance cost. The onshore cleanup costs cover machine cost, boat cost and manual cost. All the sub-costs, except booms cost, rely on the predicted time through the probabilistic network. The per unit time cost information of different resources is based on the literatures, expert opinions. Table 8.4 shows the cleanup cost estimation in the case studies.

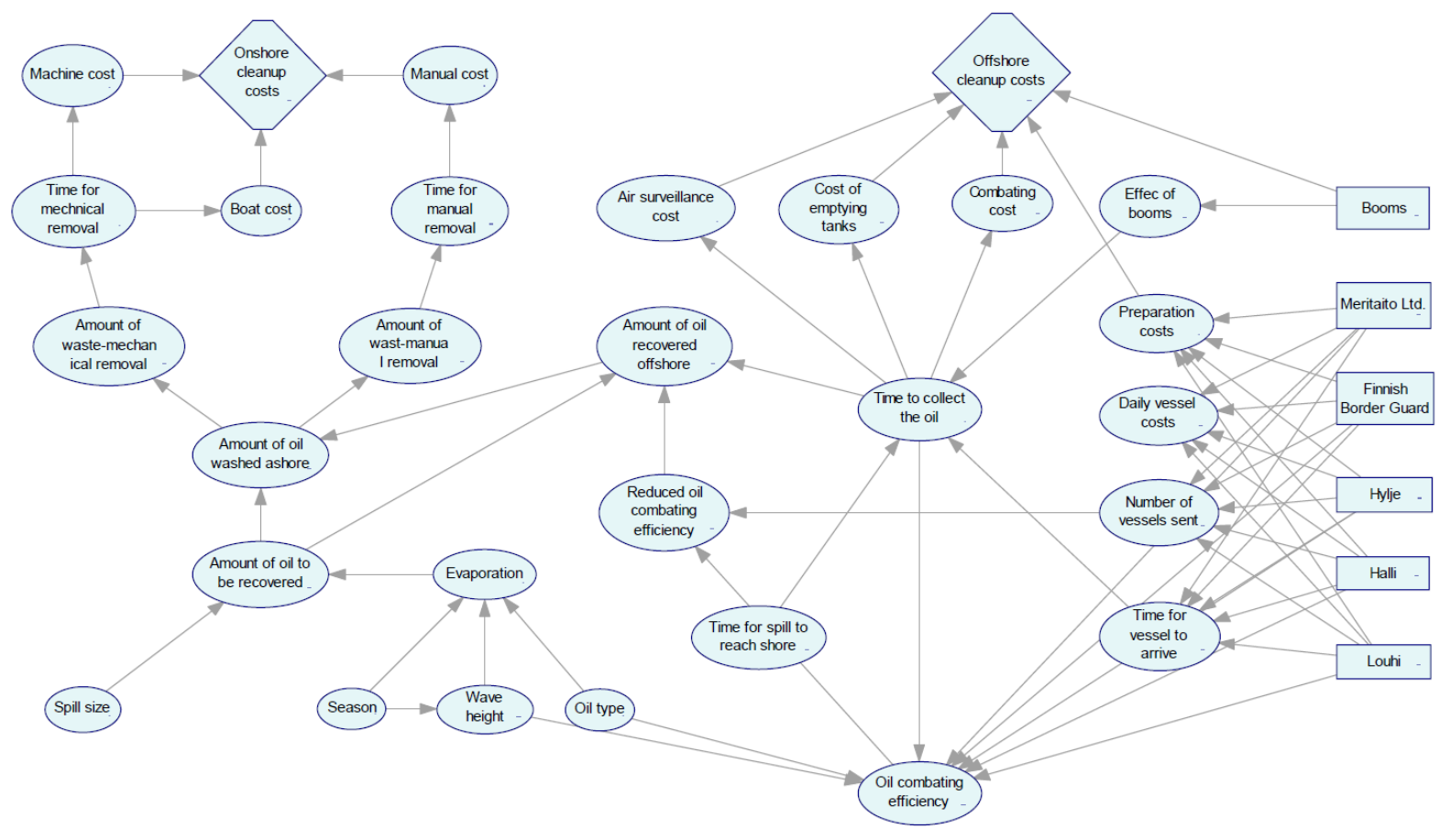

Figure 8.4 Cleanup cost estimation BN model (After Montewka et al., 2013)

Table 8.4 Estimated cleanup cost (Unit: million $€$ ) (Montewka et al., 2013)

\begin{tabular}{ccc}
\hline Scenario & 1 & 2 \\
\hline Spill volume $\left(\mathrm{m}^{3}\right)$ & 5000 & 50000 \\
Oil type & Medium oil & Heavy crude oil \\
Cleanup cost & 13.5 & 98.1 \\
\hline
\end{tabular}

With similar Bayesian network model approach, Helle et al. (2015) separated the costs further into combating operation and waste treatment operation for both open sea and shoreline responses and recoveries. The calculated costs are summarized in Table 8.5 for the case studies. 
Table 8.5 Estimated cleanup cost (Unit: million $€$ ) (Helle et al., 2015)

\begin{tabular}{ccc}
\hline Scenario & 1 & 2 \\
\hline Spill volume $\left(\mathrm{m}^{3}\right)$ & 3000 & 50000 \\
Oil type & Medium oil & Heavy crude oil \\
Combating operation & 1.5 & 1.5 \\
Open sea & 4 & 14.7 \\
Shoreline & & \\
Waste treatment operation & 0.5 & 3.7 \\
Open sea & 2.7 & 29 \\
Shoreline & 8.7 & 49 \\
Total & & \\
\hline
\end{tabular}

\subsubsection{Estimation model based on oil spill database}

This type of estimation for cleanup cost is more based on large data from historical oil spill accidents. Three models are introduced in the following sections: 1) Etkin model, 2) a limitparameter based regression model and 3) a regression model based on compensation data.

\subsection{Etkin model}

\subsection{General cleanup cost}

Etkin $(1999,2000)$ developed a method for estimating cleanup costs (per unit ton or gallon).

The approach is based on historical data over more than two hundred oil spills worldwide. The analysis focuses on the per-unit (per-ton or per-gallon) oil spill cleanup costs on various factors. The estimation formulas were derived as:

$$
\begin{gathered}
C_{e i}=C_{u i} A_{i} \\
C_{u i}=C_{l i} t_{i} o_{i} m_{i} s_{i} \\
C_{l i}=C_{n} r_{i} l_{i}
\end{gathered}
$$

where $C_{e i}$ is estimated total response cost for the scenario, $\mathrm{i} ; A_{i}$ is specified spill amount for scenario; $C_{u i}$ is response cost per unit for scenario, $\mathrm{i} ; C_{l i}$ is cost per unit spilled for scenario, $\mathrm{i} ; C_{n}$ is general cost per unit spilled in a country, $\mathrm{n}$, as shown in Table 8.6; $t_{i}$ is oil type modifier factor for scenario, $\mathrm{i} ; o_{i}$ is shoreline oiling modifier factor for scenario, $\mathrm{i} ; m_{i}$ is cleanup methodology factor for scenario, $\mathrm{i} ; s_{i}$ is spill size modifier factor for scenario, $\mathrm{i} ; r_{i}$ is regional location modifier factor for scenario, $\mathrm{i}$; and $l_{i}$ is local location modifier for scenario, $\mathrm{i}$. The modifiers are listed in Table 8.7. 
Table 8.6 General cost per unit spilled in countries (Etkin, 2000)

\begin{tabular}{|c|c|c|}
\hline Country & USD/gallon & USD/ton \\
\hline \multicolumn{3}{|l|}{ North America } \\
\hline Canada & 22.1 & 6508.1 \\
\hline United States & 87.1 & 25614.6 \\
\hline Average & 67.4 & 19814.6 \\
\hline \multicolumn{3}{|l|}{ Latin America } \\
\hline Argentina & 7.9 & 2316.6 \\
\hline Brazil & 19.0 & 5600.7 \\
\hline Chile & 3.1 & 910.4 \\
\hline Mexico & 2.9 & 850.3 \\
\hline St. Kitts/Nevis & 10.5 & 3085.8 \\
\hline Uruguay & 11.5 & 3368.3 \\
\hline Venezuela & 40.2 & 1817.8 \\
\hline Average & 10.4 & 3055.8 \\
\hline \multicolumn{3}{|l|}{ Africa } \\
\hline Egypt & 15.1 & 4428.9 \\
\hline Morocco & 32.9 & 9675.1 \\
\hline Mozambique & 0.04 & 6.1 \\
\hline Nigeria & 6.0 & 1766.8 \\
\hline South Africa & 9.9 & 2917.5 \\
\hline Average & 10.7 & 3163.9 \\
\hline \multicolumn{3}{|l|}{ Europe } \\
\hline Denmark & 38.0 & 11180.4 \\
\hline Estonia & 23.2 & 6820.6 \\
\hline Finland & 7.2 & 2115.3 \\
\hline France & 7.8 & 2301.6 \\
\hline Germany & 36.4 & 10702.7 \\
\hline Greece & 29.0 & 8530.3 \\
\hline Ireland & 16.4 & 4807.5 \\
\hline Italy & 22.3 & 6541.2 \\
\hline Latvia & 31.3 & 9212.4 \\
\hline Lithuania & 0.26 & 78.1 \\
\hline Netherlands & 22.6 & 6655.4 \\
\hline Norway & 78.6 & 23118.1 \\
\hline Spain & 1.5 & 438.7 \\
\hline Sweden & 53.2 & 15642.4 \\
\hline United Kingdom & 10.5 & 3082.8 \\
\hline Yugoslavia & 5.2 & 1541.4 \\
\hline Average & 36.7 & 10807.8 \\
\hline \multicolumn{3}{|l|}{ South Pacific } \\
\hline Australia & 20.4 & 5991.3 \\
\hline New Zealand & 9.5 & 2791.4 \\
\hline Average & 19.4 & 5698.9 \\
\hline \multicolumn{3}{|l|}{ Middle East } \\
\hline Israel & 7.9 & 2313.6 \\
\hline UAE & 2.2 & 637.0 \\
\hline Average & 3.6 & 1057.5 \\
\hline Asia & & \\
\hline
\end{tabular}




\begin{tabular}{ccc}
\hline Hong Kong, China & 15.1 & 4452.9 \\
Japan & 117.8 & 34619.9 \\
Malaysia & 260.9 & 76589.3 \\
Philippines & 2.3 & 676.5 \\
Singapore & 1.3 & 390.6 \\
South Korea & 43.6 & 12814.9 \\
Average & 93.5 & 27495.8 \\
\hline
\end{tabular}

Table 8.7 Cost factors for modifiers (Etkin, 2000)

\begin{tabular}{|c|c|}
\hline Cost factor & Modifier \\
\hline \multicolumn{2}{|l|}{ Oil type } \\
\hline No. 2 fuel (diesel) & 0.18 \\
\hline Light crude & 0.32 \\
\hline No. 4 fuel, No. 5 fuel & 1.82 \\
\hline Crude & 0.55 \\
\hline Heavy crude & 0.65 \\
\hline No. 6 fuel & 0.71 \\
\hline \multicolumn{2}{|l|}{ Spill size (gal/ton) } \\
\hline $0-1 \mathrm{E} 04 / 0-34$ & 2.00 \\
\hline $1 \mathrm{E} 04-1 \mathrm{E} 05$ / $34-340$ & 0.65 \\
\hline $1 \mathrm{E} 05-5 \mathrm{E} 05 / 340-1700$ & 0.27 \\
\hline $5 \mathrm{E} 05-1 \mathrm{E} 06 /(1700-3400$ & 0.15 \\
\hline $1 \mathrm{E} 06-1 \mathrm{E} 07 / 3400-34000$ & 0.05 \\
\hline $1 \mathrm{E} 07+/ 34000+$ & 0.01 \\
\hline \multicolumn{2}{|l|}{ Spill location } \\
\hline Nearshore & 1.46 \\
\hline In port & 1.28 \\
\hline Offshore & 0.46 \\
\hline \multicolumn{2}{|l|}{ Primary cleanup method } \\
\hline Dispersants & 0.46 \\
\hline In situ burning & 0.25 \\
\hline Mechanical & 0.92 \\
\hline Manual & 1.89 \\
\hline Natural cleansing & 0.10 \\
\hline \multicolumn{2}{|l|}{ Shoreline (km) } \\
\hline 0.1 & 0.47 \\
\hline 2.2 & 0.54 \\
\hline 20.9 & 0.61 \\
\hline 100 & 1.06 \\
\hline 500 & 1.53 \\
\hline
\end{tabular}

\subsection{On-water cleanup cost}

A further calculation tool was developed by Etkin and Welch (2005), which further divides costs into on-water and shoreline response costs based on case studies and modelling of hypothetical spills. The estimation formulae for on-water response cost can be summarized as: 


$$
\begin{gathered}
C_{r w}=C_{r w 1}+C_{r w 2}+C_{r w 3}+C_{r w 4} \\
C_{r w 1}=3236.7 A^{0.4387} \\
C_{r w 2}=35388 A^{0.2762} \\
C_{r w 3}=C_{u w i} \mathrm{~A} \\
C_{r w 4}=5 P_{r} P_{w} A
\end{gathered}
$$

Where $C_{r w}$ is on-water response cost, $C_{r w 1}$ is monitoring cost, $C_{r w 2}$ is mobilization cost, $C_{r w 3}$ is oil related cost, $C_{r w 4}$ is disposal cost. $C_{u w i}$ is cost per gallon by oil type and response type, as shown in Table 8.8. A is spill volume, $P_{r}$ is percent of oil remaining and $P_{w}$ is percent of onwater removal.

Table 8.8 Per gallon cost (USD) by oil type and response type (Etkin and Welch, 2005)

\begin{tabular}{cccc}
\hline Oil type & Mechanical & Response Type & \\
& 28 & Burn & Dispersant \\
\hline Medium crude & 12 & 23 & 24 \\
Gasoline & 12 & NA & NA \\
Jet fuel & 15 & NA & NA \\
Diesel & 23 & 13 & 14 \\
Light crude & 36 & 29 & 19 \\
Heavy crude & 37 & 30 & 30 \\
No. 6 Fuel & 28 & 28 & 31 \\
IFO & 26 & 21 & 24 \\
Lube oil & 26 & 22 \\
\hline
\end{tabular}

NA means the response type is not recommended for that oil type, thus no cost data.

\subsection{Shoreline cleanup cost}

In addition to the on-water cleanup cost, Etkin and Welch (2005) described the corresponding calculations for shoreline response cost. The estimation formula is concluded here as:

$$
C_{s r}=f_{H C I C} \sum_{i=1}^{n} C_{u s i} S_{i} f_{c i}
$$

Where $C_{s r}$ is shoreline response cost, $C_{u s i}$ is shoreline response cost per area by oil thickness for shoreline type i, $S_{i}$ is shoreline oiled area, $f_{c i}$ is coverage adjustment factor and $f_{H C I C}$ is HCIC (How Clean Is Clean) adjustment factor. Table 8.9 shows an example of $C_{u s i}$ for medium crude oil type. 


$$
\begin{aligned}
& f_{c}=\left\{\begin{array}{l}
3.0, \text { C, continous } \\
2.3, \text { B, broken } \\
1.0, \text { P, patchy } \\
0.2, \text { S, sporadic }
\end{array}\right. \\
& f_{\text {HCIC }}=\left\{\begin{array}{l}
2.7, \text { Maximum } \\
1.2, \text { High } \\
1.0, \text { Medium } \\
0.8, \text { Low } \\
0.4, \text { Minimum }
\end{array}\right.
\end{aligned}
$$

Table 8.9 Medium crude oil shoreline spill cost (USD/m²) (Etkin and Welch, 2005)

\begin{tabular}{lccccc}
\hline Shoreline Type & $\begin{array}{c}\text { Pooled } \\
\text { Oil } \\
1+\mathrm{cm}\end{array}$ & $\begin{array}{c}\text { Cover } \\
0.1-1 \mathrm{~cm}\end{array}$ & $\begin{array}{c}\text { Coat } \\
0-0.1 \mathrm{~cm}\end{array}$ & Stain & Film \\
\hline 1A: Exposed rocky & 159 & 59 & 15 & 6 & 3 \\
2: Rocky platform & 159 & 59 & 15 & 6 & 3 \\
3: Fine sand & 159 & 59 & 15 & 6 & 3 \\
4: Coarse sand & 159 & 59 & 15 & 6 & 3 \\
5: Mixed sand/gravel & 193 & 71 & 18 & 8 & 4 \\
6A: Gravel beach & 193 & 71 & 18 & 8 & 4 \\
6B: Riprap structures & 193 & 71 & 18 & 8 & 4 \\
7: Exposed tidal flat & 259 & 96 & 24 & 10 & 5 \\
8A: Sheltered rocky shore & 159 & 59 & 15 & 6 & 3 \\
8B: Sheltered solid & 125 & 46 & 12 & 5 & 3 \\
9: Sheltered tidal flat & 259 & 96 & 24 & 10 & 5 \\
10A: Salt/brackish marsh & 259 & 96 & 24 & 10 & 5 \\
10B: Freshwater marsh & 259 & 96 & 24 & 10 & 5 \\
10C: Swamp & 259 & 96 & 24 & 10 & 5 \\
10D: Mangrove & 259 & 96 & 24 & 10 & 5 \\
\hline
\end{tabular}

\subsection{A limit-parameter based regression model}

Shahriari and Frost (2008) developed a mathematical method to estimate cleanup costs based on regression analysis of 80 incidents during period of 1967-2002. The model parameters are spill quantity, oil density, distance to shore, cloudiness and level of preparedness.

In order to reach predictions as reliable as possible, the composite model is used, i.e.

$$
\begin{gathered}
C_{c 1}=156.5934 A+56781000 \rho+2303500 L_{p}-4979000 \\
C_{c 2}=\left(29471 \rho+863.0906 L_{p}-24060\right) A
\end{gathered}
$$


Where $C_{c 1}$ and $C_{c 2}$ are cleanup cost estimations by two approaches, $\mathrm{A}$ is spill amount in tones, $\rho$ is oil density in $\mathrm{kg} / \mathrm{m} 3, L_{p}$ is level of preparedness, ITOPF estimations of how well different regions cope with oil spills, on a scale of $1-3,3$ being best.

The model user need to use both equations and then decide which prediction to use, based on the cost interval $\left[4 \times 10^{6}\right.$ to $\left.4 \times 10^{7}\right]$. If both predictions end up within the interval, choose $C_{c 1}$. If both end up outside the interval, choose $C_{c 2}$.

\subsection{A regression model based on compensation data}

Kontovas et al. (2010) developed a method to estimate the cleanup cost by using the data of compensations paid by the International Oil Pollution Compensation Fun (IOPCF). The formula developed is expressed as:

$$
C=44435 A^{0.644}
$$

Where $\mathrm{C}$ is cleanup cost in US\$ and A is spill size in tones.

\subsubsection{Natural resource damages}

\subsubsection{Estimation based on recovery function}

A degradation of natural resources will happen after oil spill and, consequently, decreases their services. Liu and Wirtz (2009) developed an estimation method for lost service value of natural resources after oil impacts. As shown in Figure 8.5, the lost services are represented by the time-integrated area $L$, which can be estimated in terms of the fraction $f(t)$ of intact services. The fraction $f(t)$ can be a time-dependent recovery function, then L sums over the years of loss until the injured resource is completely restored. The formula can be expressed as:

$$
L=\sum_{t=a}^{b}(1-\mathrm{f}(\mathrm{t}))\left(\frac{1}{1+d}\right)^{t-a}
$$




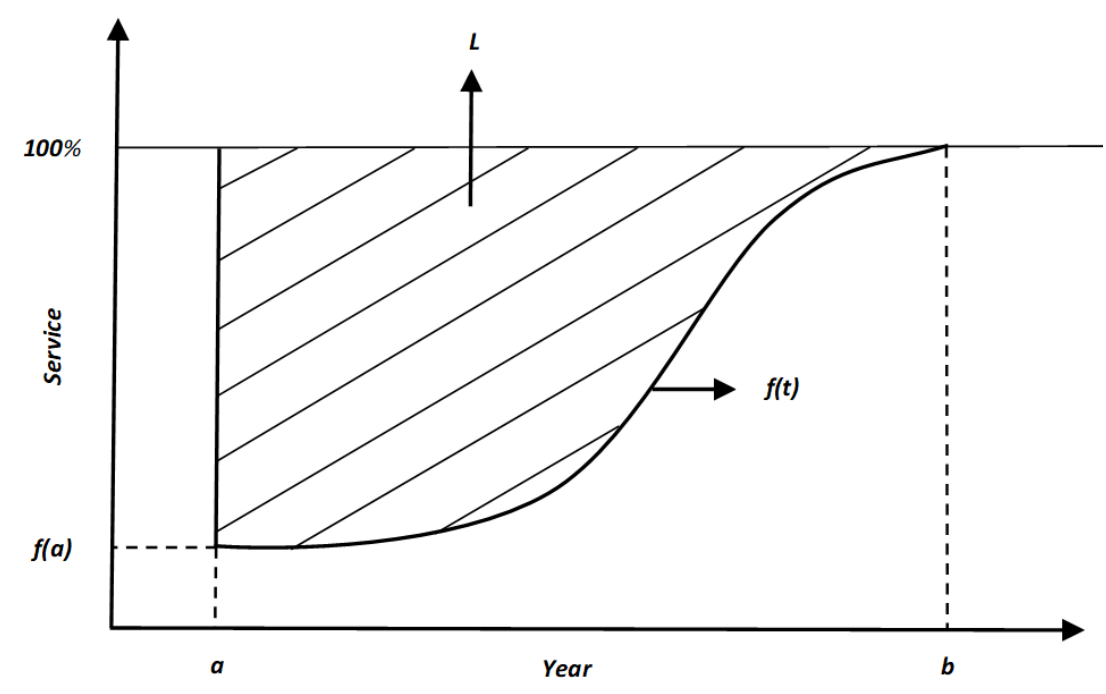

Figure 9.5 Time intergral over lost service L. $f(t)$ is a recovery function to describe the potential service provided by the injured habitats during the year $\mathrm{t}$.

Where $d$ is the yearly discount rate reflecting that the present service losses are more costly than the future ones. A value of $d=0.03$ is recommended (NOAA, 1999).

The total value lost $\mathrm{T}$ is expressed as aggregation over individual losses related to each resource:

$$
T=\sum_{i=1}^{n} \mathrm{~V}_{i}=\sum_{i=1}^{n} \mathrm{M}_{i} \mathrm{Q}_{i} \mathrm{~L}_{i}
$$

Where $Q_{i}$ is the total amount of injured resource $i$ and $M_{i}$ is monetary value per unit for resource $\mathrm{i}, \mathrm{n}$ is the number of resources damaged by the released oil.

$\mathrm{M}_{i}$ is difficult to define as most of the environmental goods and services are non-marketed. Currently, there are two key ways to get the unit value of nonmarket resources: 1) measure through direct or indirect economic means, 2) transfer an estimated value from past studies (Liu and Wirtz, 2006). The first way requires application of valuation methods to measure the value and there are four categories (Turner et al., 1995): the constructed market valuation (CMV) methods, surrogate market valuation (SMV) methods, market oriented valuation (MOV) methods and cost-based valuation methods (CBV). The details of the methods will not be discussed here. It should be noted that the value of environmental resources discussed here refer to both use and non-use values. The estimates derived from CMV, SMV and MOV 
method emphasize losses of value based on the people's willingness to pay (WTP) in a real or hypothetical market.

\subsubsection{Estimation model based on oil spill database}

Etkin and Welch (2005) also includes the estimation for natural resource damage. The formulas for on-water natural resource damage are summarized here as:

$$
T=\sum_{i=1}^{n} \mathrm{~V}_{i}=\sum_{i=1}^{n} S_{i} G d_{o} G^{-x_{o}}
$$

Where $\mathrm{T}$ is the total value lost, $\mathrm{V}_{i}$ is the lost value for natural resource $\mathrm{i}, S_{i}$ is the natural resource $\mathrm{i}$ modifier, $\mathrm{G}$ is the spill amount in gallons, $d_{o} G^{-x_{o}}$ calculates per gallon resource damage, $d_{o}$ and $x_{o}$ are the factors for different oil types.

$$
\begin{aligned}
& d_{o}=\left\{\begin{array}{l}
186.69, \text { gasoline or jet fuel } \\
274.15, \text { diesel or LT crude } \\
279.3, \text { medium crude, lube oil or IFO } \\
256.28, \text { Hvy crude or No. } 6 \text { Fuel }
\end{array}\right. \\
& x_{o}=\left\{\begin{array}{l}
0.1961, \text { gasoline or jet fuel } \\
0.1634, \text { diesel or LT crude } \\
0.1525, \text { medium crude, lube oil or IFO } \\
0.1366, \text { Hvy crude or No. } 6 \text { Fuel }
\end{array}\right.
\end{aligned}
$$

$$
S_{i}=\left\{\begin{array}{l}
2.5, \text { fish } \\
3.0, \text { mammals } \\
4.0, \text { other high } \\
4.5, \text { birds } \\
3.5, \text { coral reef } \\
1.0, \text { low }
\end{array}\right.
$$

Similarly, the estimation formulas for shoreline natural resource damage are summarized as:

$$
T=(1-e) \sum_{i=1}^{n} \mathrm{~V}_{i}=\sum_{i=1}^{n} S_{i} C d_{o} C^{-x_{o}}
$$

Where $\mathrm{C}$ is actual amount that hit shoreline, the natural resource modifier $S_{i}$ is:

$$
S_{i}=\left\{\begin{array}{l}
4.0, \text { birds } \\
2.7, \text { mammals } \\
5.0, \text { endangered species } \\
4.0, \text { highly sensitive } \\
2.0, \text { moderate sensitive } \\
0.3, \text { low sensitive }
\end{array}\right.
$$




\subsubsection{Socioeconomic loss}

\subsubsection{Estimation based on recovery function}

The oil pollution will also cause losses to various socioeconomic aspects, e.g. fishery and tourism by reducing their profits. Similar to a contaminated natural resource, the affected economic sectors also need time to recover from the pollution. Their economic losses (EL) are the sum of reduced incomes during their recovery period:

$$
E L=\sum_{i=1}^{n} y r_{i} \sum_{t=0}^{p_{i}}\left(1-\mathrm{f}_{i}(\mathrm{t})\right)\left(\frac{1}{1+d}\right)^{t}
$$

Where $y r_{i}$ is the yearly revenue for economic sector $i, \mathrm{f}_{i}(\mathrm{t})$ represents the relative percent of service provided by the affected sector $i$ at year $t$ following the incident, $d$ denotes a yearly discount rate and $p_{i}$ quantifies the required period in years for a full recovery (Liu and Wirtz 2009).

\subsubsection{Estimation model based on oil spill database}

Similar to natural resource damage calculation (Etkin and Welch, 2005), the estimation formula for socioeconomic loss can be categorized into on-water and shoreline types. The on-water socioeconomic loss can be summarized as:

$$
T=\sum_{i=1}^{n} \mathrm{~V}_{i}=\sum_{i=1}^{n} S_{i} G d_{o} G^{-x_{o}}
$$

Where $\mathrm{T}$ is the total value lost, $\mathrm{V}_{i}$ is the lost value for natural resource $\mathrm{i}, S_{i}$ is the socioeconomic resource i modifier, $\mathrm{G}$ is the spill amount in gallons, $d_{o} G^{-x_{o}}$ calculates per gallon resource damage, $d_{o}$ and $x_{o}$ are the factors for different oil types.

$$
\begin{aligned}
& d_{o}=\left\{\begin{array}{c}
1625.6, \text { gasoline or jet fuel } \\
2076, \text { diesel } \text { or } L T \text { crude } \\
4407, \text { medium } \text { crude, lube oil or IFO } \\
1370.8, \text { Hvy crude or No. } 6 \text { Fuel }
\end{array}\right. \\
& x_{o}=\left\{\begin{array}{l}
0.2166, \text { gasoline or jet fuel } \\
0.2226, \text { diesel } \text { or } \text { LT crude } \\
0.2283, \text { medium } \text { crude, lube oil or IFO } \\
0.2236, \text { Hvy crude or No. } 6 \text { Fuel }
\end{array}\right.
\end{aligned}
$$




$$
S_{i}=\left\{\begin{array}{l}
2.9, \text { fisheries } \\
2.4, \text { ports } \\
1.0, \text { boating } \\
1.4, \text { water intake } \\
2.9, \text { drink water } \\
1.4, \text { rec fishing } \\
1.4, \text { other high use } \\
0.4, \text { low use }
\end{array}\right.
$$

Likewise, the estimation formula for shoreline socioeconomic loss can be summarized as:

$$
T=(1-e) \sum_{i=1}^{n} \mathrm{~V}_{i}=\sum_{i=1}^{n} S_{i} C d_{o} C^{-x_{o}}
$$

Where $\mathrm{C}$ is actual amount that hit shoreline, the socioeconomic resource modifier $S_{i}$ is:

$$
S_{i}=\left\{\begin{array}{l}
1.4, \text { tourist beach } \\
2.4, \text { wildlife viewing } \\
0.1, \text { industial } \\
0.4, \text { port } \\
1.0, \text { residential } \\
2.9, \text { high value } \\
1.0, \text { medium value } \\
0.4, \text { low value }
\end{array}\right.
$$

\subsubsection{Other costs}

The final category of oil spill impact includes research and legal costs, the value of the lost cargo and tanker or platform, and damages to the health, etc. (Grigalunas et al, 1986; Gill et al., 2016). Research costs are the expenditures used for scientists to investigate on the influence of oil spills on the environment and society. There are not too much study on the research cost. The three oil spill research cost reported (Grigalunas et al, 1986; Liu and Wirtz, 2009) include: 1) Amoco Cadiz spill (1978), 3.8 million US dollars; 2) Exxon Valdez (1989), 250-270 million US dollars; 3) Prestige spill (2002), 10 million euros.

Legal cost information is viewed as a proprietary and thus usually unavailable. Conceptually, it can be measured by summing the value of the time spent by litigants and other marginal legal costs.

The value of the lost cargo and tanker or platform can be estimated according to the market value. However, damages to the health is difficult to estimate. The effect on the health may 
come from the air, the water and the polluted sea food, etc. The short or long term effects are usually not obvious. In addition, the research studies (IAI, 1990; Gill et al., 2016) show that psychological impacts cause additional public health cost etc.

\subsection{Global economic impact}

The global economic impacts are almost not possible to be quantitatively assessed and the impacts can be only visible for very large oil spill accidents. Financial market may be one of the networks which spread the impacts globally. For example, when the Deepwater Horizon oil spill happened, BP share price fluctuated immediately and changed with the corresponding oil spill controls and updates, as indicated in Figure 8.6. The company finance and strategies can also be influenced and changed correspondingly. In addition, even the oil prices may also be under impacts. Therefore, the whole industry networks will be affected further in cases of severe oil spill accidents.

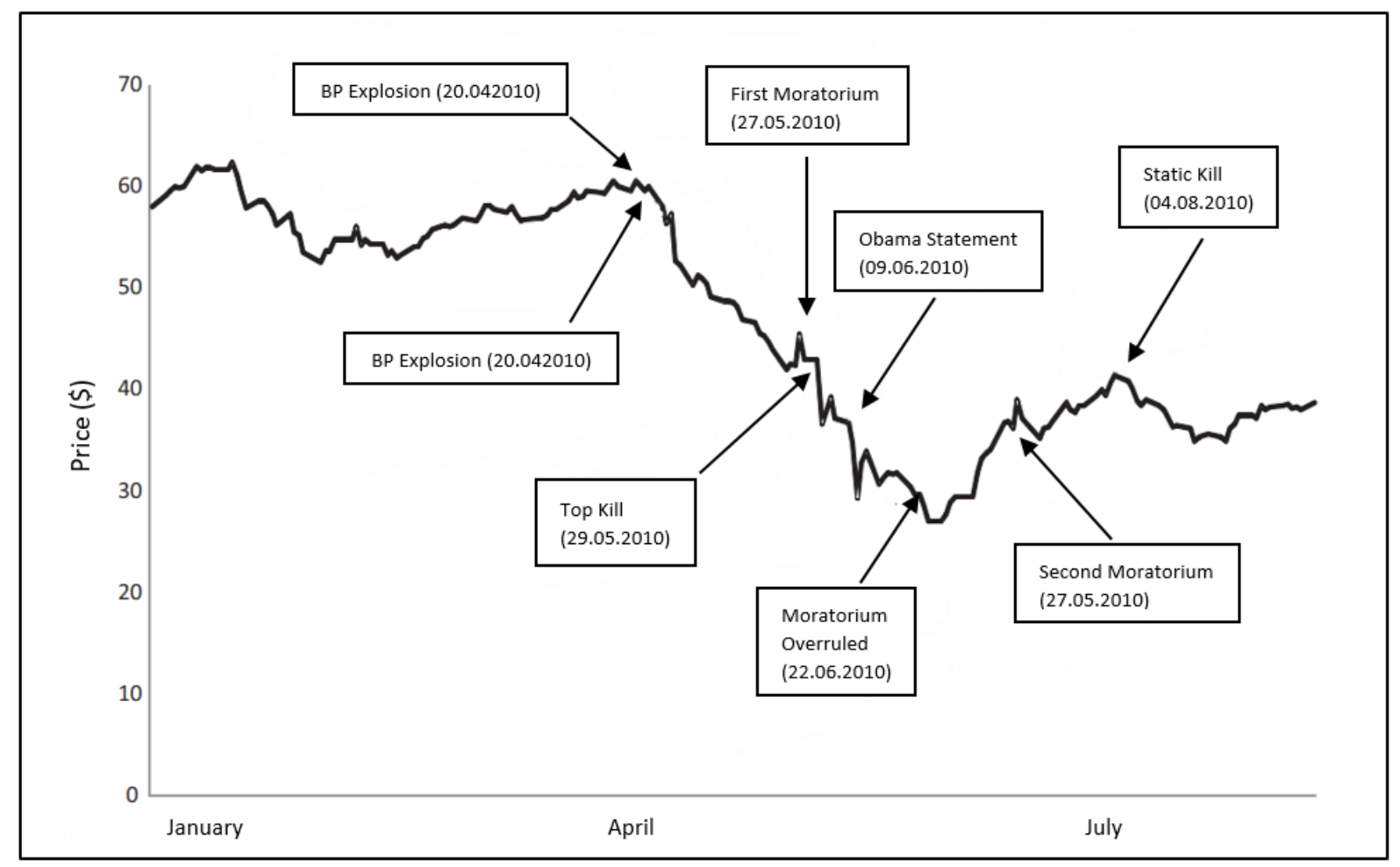

Figure 8.6 BP P.L.C. share price (\$). It shows BP P.L.C. daily share prices from 1 January 2010 to 15 September 2010 and significant dates following the BP oil spill explosion (After Sabet et al., 2012). 
In addition, not only local research costs may be caused as mentioned in section 2.1.4, research costs can also be induced globally. The research and policy may further form new regulations, technologies, and marine activities, which will impact the oil and gas industry, shipping and ship industry globally as well.

\section{Major oil spills: compensation, claim and cost estimation}

Some major oil spill accidents have happened worldwide. Figure 8.7 shows a distribution of waters with major oil spills from tankers. Some accidents such as Deepwater Horizon are thus not listed in the map. This section will firstly illustrate compensation regime for tankers, i.e. the International Oil Pollution Compensation Funds (IOPC Funds) shortly and then present some examples of the major accidents on the compensations, claims and estimated cost.

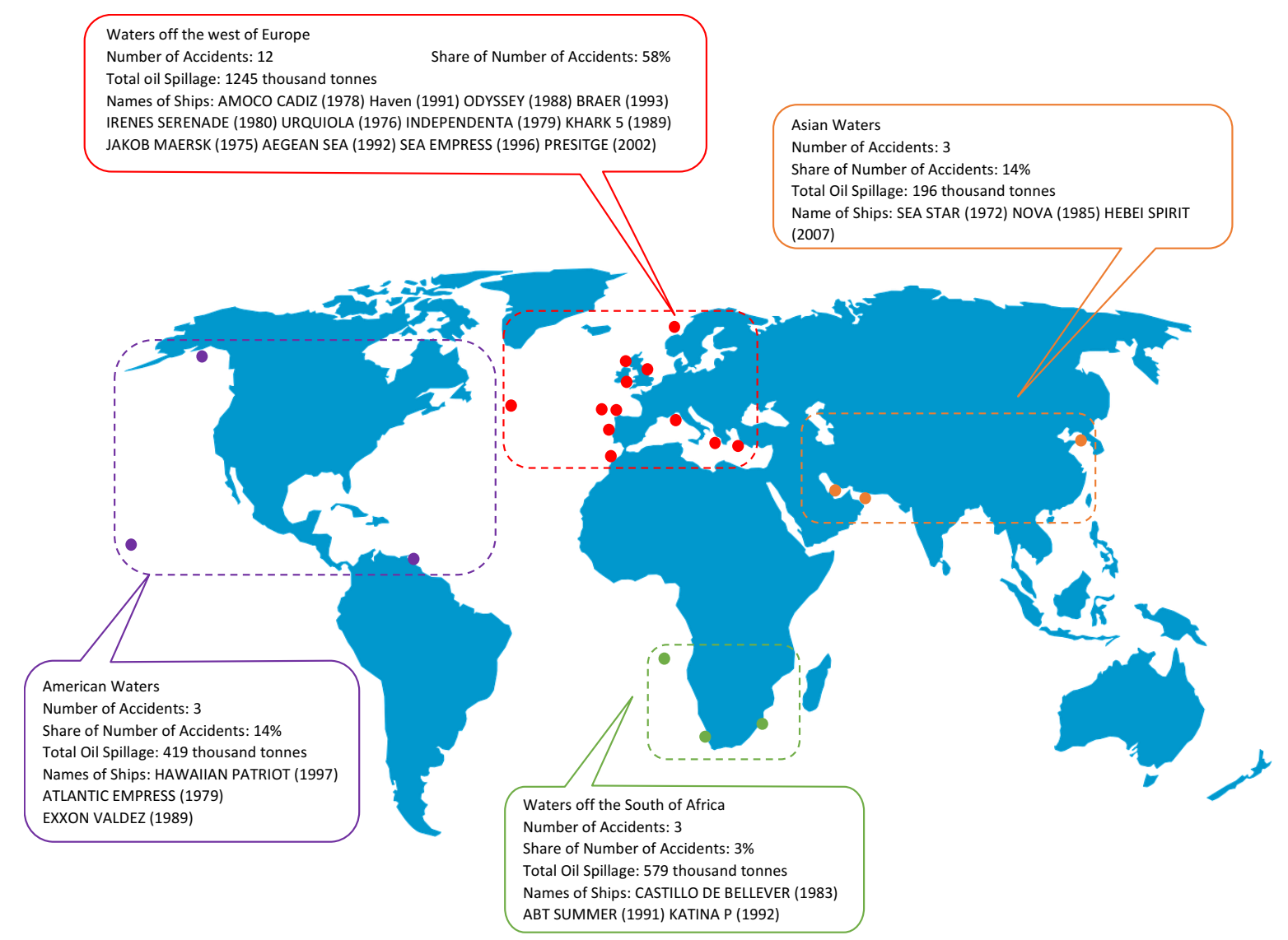

Figure 8.7 Distribution of waters with major oil spill accidents from 1970 to 2017, Source:

ITOPF (After Chen et al., 2019)

It is known that the original basis of compensation regime for oil pollution caused by tankers are the 1969 International Convention on Civil Liability for Oil Pollution Damage (CLC 1969) 
and the 1971 International Convention on the Establishment of an International Fund for Compensation for Oil Pollution (1971 Fund). Two additional legal instruments, the 1992 Civil Liability Convention (CLC 1992) and the 1992 Fund Convention (1992 Fund) were created as the amount of compensation required to cover larger oil spill incidents increased. In addition, a third legal instrument, the Supplementary Fund Protocol to the 1992 Fund Convention was adopted in 2003 to provide additional compensation to affected stakeholders when the compensation payment exceeds the limit under the CLC 1992 and the 1992 Fund. Therefore, the International Oil Pollution Compensation Funds (IOPC Funds) is now composed of three intergovernmental agreements: the 1971 Fund, the 1992 Fund, and the Supplementary Fund, which provide financial compensation for property damage, oil cleanup operation, and economic losses caused by oil spill incidents occurring in member states (Kim et al., 2014). The 1971 Fund Convention expired in May, 2002 but continues to deal cases with oil spill incidents that occurred before the expired date.

The flag of the vessel which causes oil spill, the ownership of the oil cargo or the location of the incident (as long as the damage occurs in a member state) is not related to the provision of financial compensation for oil pollution under the CLC and the 1992 Fund (IOPC Funds, 2014). First, the costs are paid by individual tanker owner up to the relevant CLC limit through a compulsory insurance and then by IOPC Funds. If the accepted claims exceed the Fund limit, every claimant is treated equally and receives corresponding proportion of their claims and the Supplementary Fund will work for its relevant members to provide additional compensation to affected stakeholders.

Table 8.10 summarizes compensations, claims and estimated costs from different sources for some major oil spill accidents in Figure 8.7. It can be seen that a relatively low rate of compensation is paid by IOPC Funds, which may be related to the reason that the non-use values were disregarded in the damage assessment. Meanwhile, there are also difficulties from 
giving proofs to establish the damage incurred by oil spill pollution (Kim et al., 2014). The compensation rate is high in case of Exxon Valdez oil spill. This is because the United States legal system did not permit limitation of liability, contrary to the IOPC Funds regime, which allows the compensation to the non-use values of the natural resource (Carson et al., 2003; Kim et al., 2014). In USA, the oil pollution damage has been regulated by Oil Pollution Act of 1990, enacted after Exxon Valdez oil spill.

In general, from Table 8.10 , it can be seen that major oil spills usually caused huge economic losses and the claims cannot be met by IOPC Funds sorely. Some governmental involvements make the compensations better. In some cases, the estimated costs may somehow reflect the economic damages, but vary a lot for different situations. More efforts and studies are still needed to understand the impacts better. 
Table 8.10 Damage estimation and compensation for some oil spill incidents (Unit: in USD in millions). (After Kim et al., 2014 and Thébaud et al., 2004. In Thébaud et al., 2004, $1 £=1.45 \$$ is used to transfer the reported numbers in year 2001)

\begin{tabular}{|c|c|c|c|c|c|c|c|}
\hline \multirow[t]{2}{*}{ Case } & \multirow{2}{*}{$\begin{array}{l}\text { Size of oil } \\
\text { spilled }\left(\mathrm{m}^{3}\right)\end{array}$} & \multicolumn{3}{|c|}{ Damage estimation } & \multirow[t]{2}{*}{ Claims } & \multirow{2}{*}{$\begin{array}{l}\text { IOPC funds } \\
\text { limits (CLC }+ \\
\text { fund limit) }\end{array}$} & \multirow[t]{2}{*}{ Compensation } \\
\hline & & Reference & Estimated damage & & & & \\
\hline \multirow{2}{*}{$\begin{array}{l}\text { Amoco Cadiz } \\
(1978, \text { France })\end{array}$} & \multirow[t]{2}{*}{$\sim 220000$} & Thébaud et al., 2005 & Global cost of damages & $624.4-716.6$ & \multirow[t]{2}{*}{681.4} & & \multirow[t]{2}{*}{132.5} \\
\hline & & $\begin{array}{l}\text { Grigalunas et al, } \\
1986\end{array}$ & Total net costs to world & $195-284$ & & & \\
\hline \multirow{6}{*}{$\begin{array}{c}\text { Tanio } \\
\text { (1980, France) } \\
\text { Exxon Valdez } \\
(1989, \text { USA })\end{array}$} & $\sim 13500$ & \multicolumn{2}{|l|}{ Thébaud et al., 2005} & & 160.5 & & 49.7 \\
\hline & 45202 & Carson et al. 1992 & CVM value & 4990.0 & \multirow{5}{*}{$\begin{array}{l}2140.0 \text { (including } \\
1250.0 \text { for civil } \\
\text { claims }+891 \text { for } \\
\text { criminal fines) }\end{array}$} & \multirow{5}{*}{$\begin{array}{l}\text { N/A (not a } \\
\text { member) }\end{array}$} & \multirow{5}{*}{$\begin{array}{l}6059.0 \text { by Exxon } \\
\text { (including } 4455.0 \\
\text { for cleanup }+1604.0 \\
\text { for civil settlement } \\
\text { by Exxon) }\end{array}$} \\
\hline & & Carson et al. 2003 & CVM value & 12820.0 & & & \\
\hline & & $\begin{array}{l}\text { Rodgers Jr et al. } \\
2005\end{array}$ & $\begin{array}{l}\text { Civil damages, fines, and } \\
\text { restitution }\end{array}$ & 2227.0 & & & \\
\hline & & Perry, 2010 & $\begin{array}{l}\text { Punitive damages } \\
\text { (awarded by the jury) }\end{array}$ & 7859.0 & & & \\
\hline & & $\begin{array}{l}\text { Allo and Loureiro, } \\
2013\end{array}$ & Economic damage & 4553.0 & & & \\
\hline \multirow{2}{*}{$\begin{array}{c}\text { Aegean Sea } \\
(1992, \text { Spain }) \\
\text { Braer } \\
(1993, \text { UK })\end{array}$} & $\sim 80000$ & Thébaud et al., 2005 & & & 338 & & 16.0 \\
\hline & $\sim 86500$ & Thébaud et al., 2005 & & & 223.9 & & 83.8 \\
\hline \multirow{8}{*}{$\begin{array}{l}\text { Sea Empress } \\
(1996, \text { UK) }\end{array}$} & \multirow[t]{8}{*}{83880} & Elliott and LTD, & Direct costs & $116.8-138.2$ & \multirow[t]{8}{*}{$76.1-114.2$} & \multirow[t]{8}{*}{122.8} & \multirow[t]{8}{*}{85.9 by IOPC Fund } \\
\hline & & 2001 & Tourism & $9.5-10.9$ & & & \\
\hline & & & Commercial fisheries & $16.2-23.8$ & & & \\
\hline & & & Recreational fisheries & $1.9-2.9$ & & & \\
\hline & & & Human health & $2.9-7.1$ & & & \\
\hline & & & Conservation/non-use & $53.5-84.2$ & & & \\
\hline & & Thebaud et al., 2005 & Global cost of damages & $114.3-239.1$ & & & \\
\hline & & $\begin{array}{l}\text { Allo and Loureiro, } \\
2013\end{array}$ & Economic damage & 67.5 & & & \\
\hline \multirow{5}{*}{$\begin{array}{c}\text { Erika } \\
(1999, \text { France })\end{array}$} & \multirow[t]{5}{*}{23067} & Thebaud et al., 2005 & Global cost of damages & $973-1130$ & \multirow[t]{5}{*}{507.0} & \multirow[t]{5}{*}{264.1} & \multirow{5}{*}{$\begin{array}{l}722.5 \text { (including } \\
169.1 \text { by IOPC Fund } \\
553.4 \text { by defendants) }\end{array}$} \\
\hline & & Bonnieux, 2006 & Ecological damage & 549.1 & & & \\
\hline & & IOPC Funds, 2013 & Material damage & 234.3 & & & \\
\hline & & & Moral damage & 48.3 & & & \\
\hline & & & $\begin{array}{l}\text { Pure environmental } \\
\text { damage }\end{array}$ & 6.1 & & & \\
\hline
\end{tabular}




\begin{tabular}{|c|c|c|c|c|c|c|c|}
\hline & & $\begin{array}{l}\text { Allo and Loureiro, } \\
2013\end{array}$ & Economic damage & 255.7 & & & \\
\hline \multirow[t]{13}{*}{$\begin{array}{c}\text { Prestige } \\
(2002, \text { Spain) }\end{array}$} & 73628 & Loureiro et al., 2006 & $\begin{array}{l}\text { Commercial and } \\
\text { environmental losses }\end{array}$ & 374.0 & 1494.0 & 219.5 & $\begin{array}{l}1460.1 \text { (including } \\
164.1 \text { by IOPC Fund }\end{array}$ \\
\hline & & & $\begin{array}{l}\text { Cleaning-up, recovery } \\
\text { and other palliative } \\
\text { measurements }\end{array}$ & 729.5 & & & $\begin{array}{l}+162.7 \text { by European } \\
\text { Commission }+1133 \\
\text { by Spanish }\end{array}$ \\
\hline & & & $\begin{array}{l}\text { Other expenditures } \\
\text { including transfer to } \\
\text { fishermen and shellfish } \\
\text { pickers }\end{array}$ & 326.9 & & & Government \\
\hline & & $\begin{array}{l}\text { Garza-Gil et al., } \\
2006\end{array}$ & $\begin{array}{l}\text { Losses in coastal fishing } \\
\text { sectors }\end{array}$ & 37.4 & & & \\
\hline & & & Losses in aquaculture & 7.9 & & & \\
\hline & & Garza et al., 2009 & Cleanup (marketed) & 800.6 & & & \\
\hline & & & CVM value & $1763-2240$ & & & \\
\hline & & & Fisheries (marketed) & 976.8 & & & \\
\hline & & & Tourism (marketed) & 144.6 & & & \\
\hline & & & $\begin{array}{l}\text { Recreation (non- } \\
\text { marketed) }\end{array}$ & 124.5 & & & \\
\hline & & & $\begin{array}{l}\text { Biodiversity (non- } \\
\text { marketed) }\end{array}$ & 1236.3 & & & \\
\hline & & Loureiro et al., 2009 & CVM value & 833.9 & & & \\
\hline & & $\begin{array}{l}\text { Allo and Loureiro, } \\
2013\end{array}$ & & 1481.8 & & & \\
\hline $\begin{array}{l}\text { Hebei Spirit } \\
(2007, \text { Korea })\end{array}$ & 12547 & N/A & & & 3990.0 & 300.0 & 1600.0 \\
\hline \multirow{3}{*}{$\begin{array}{l}\text { Deepwater Horizon } \\
\text { (2010, Gulf of } \\
\text { Mexico ) }\end{array}$} & $\sim 780000$ & Smith et al., 2011 & Estimated costs & 36900 & & & \\
\hline & & $\begin{array}{l}\text { Lee et al., 2018; BP } \\
\text { annual report, 2010- } \\
2016\end{array}$ & Net costs & 62585 & & & \\
\hline & & Lee et al., 2018 & Ultimate costs & 145925 & & & \\
\hline
\end{tabular}




\section{Summary}

This chapter discussed the economic and financial impacts of oil spills. Firstly, oil, oil spill, response and recovery systems are described and offshore oil spills are identified as main targets in this chapter. Secondly, subdivisions of oil spill economic and financial impacts are introduced and estimation methods and models are summarized. Lastly, some major oil spill accidents are summarized with the compensation, claims and estimated costs.

The major oil spills usually cause large impacts on the ecology and society and the compensations are often not sufficient. Additionally, the impacts may last for a long period. Therefore oil spill prevention and preparedness are always important to avoid and mitigate the oil spill and its economic and environmental impacts. Meanwhile, new challenges from more marine activities in ice infested regions may require more emphasis on both technical and economic researches. 


\section{Reference}

Allo, M., Loureiro, M.L., 2013. Estimating a meta-damage regression model for large accidental oil spills. Ecol. Econ. 86, 167-175.

Bonnieux, F., 2006. Evaluation économique du préjudice écologique causé par le naufrage de l'Erika. Rapport confidentiel.

Carson, R.T., Mitchell, R.C., Hanemann, M., Kopp, R.J., Presser, S., Ruud, P.A., 1992. A Contingent Valuation Study of Lost Passive use Values Resulting from the Exxon-Valdez oil Spills. Report to the Attorney General of Alaska.

Carson, R.T., Mitchell, R.C., Hanemann, M., Kopp, R.J., Presser, S., Ruud, P.A., 2003. Contingent valuation and lost passive use: damages from the Exxon Valdez oil spill. Environ. Resour. Econ. 25, 257-286.

Chang, S. E., J. Stone, K. Demes, and M. Piscitelli. 2014. Consequences of oil spills: a review and framework for informing planning. Ecology and Society 19(2): 26.

Chen, J., Zhang, W., Wan, Z., Li, S., Huang, T., Fei, Y., 2019. Oil spills from global tankers: Status review and future governance. Journal of Cleaner Production 227, 20-32.

Devold, H., 2013. Oil and gas production handbook: An introduction to oil and gas production, transport, refining and petrochemical industry.

Elliott, M., LTD, P., 2001. Economic for the Environment Consultancy LTD (EFTEC): Study on the Valuation and Restoration of Damage to Natural Resources for the Purpose of Environmental Liability, European Commission, Directorate-General Environment, Brüssel.

Emergency Prevention, Preparedness and Response (EPPR), 2015. Guide to Oil Spill Response in Snow and Ice Conditions.

Etkin, D.S. 1999. Estimating cleanup costs for oil spills. Proc. 1999 International Oil Spill Conf.: pp. 35-39.

Etkin, D.S. 2000c. Worldwide analysis of oil spill cleanup cost factors. Proc. 23rd Arctic \& Marine Oilspill Program Tech. Sem.: pp. $161-174$.

Etkin, D.S., Welch, J., 2005. Oil spill response cost-effectiveness analytical tool (OSRCEAT).

Garza-Gil, M.D., Surís-Regueiro, J.C., Varela-Lafuente, M.M., 2006. Assessment of economic damages from the Prestige oil spill. Mar. Policy 30 (5), 544-551.

Garza, M.D., Prada, A., Varela, M., Rodríguez, M.X.V., 2009. Indirect assessment of economic damages from the Prestige oil spill: consequences for liability and risk prevention. Disasters 33, 95-109.

Gill, D.A., Ritchie, L.A., Picou J. S., 2016. Sociocultural and psychosocial impacts of the exxon valdez oil spill: Twenty-four years of research in Cordova, Alaska. The Extractive Industries and Society 3, 1105-1116. 
Grigalunas, T.A., Anderson, R.C., Brown, G.M., Congar, R., Meade, N.F., Sorensen, P.E., 1986. Estimating the Cost of Oil Spills: Lessons from the Amoco Cadiz incident. Marine Resource Economics, Volume 2, No.3

Helle I., Ahtiainen, H., Luoma, E., Hänninen, M., Kuikka, S., 2015. A probabilistic approach for cost-benefit analysis of oil spill management under uncertainty: A Bayesian network model for the Gulf of Finland. Journal of Environmental Management. 158, 122-132.

International Maritime Organization (IMO). 2010. Manual on Oil Spill Risk Evaluation and Assessment of Response Preparedness.

Impact Assessment, Inc., 1990. Final report: economic, social, and psychological impact assessment of the Exxon Valdez oil spill.

IOPC Funds, 2013. Incidents Involving the IOPC Funds 2012. International Oil Pollution Compensation Funds, London, United Kingdom.

IOPC Funds, 2014. The International Regime for Compensation for oil Pollution Damage: Explanatory Note. International Oil Pollution Compensation Funds, London, United Kingdom, pp. 1-11.

Kim, D., Yang, G., Min, S., Koh, C., 2014. Social and ecological impacts of the Hebei Spirit oil spill on the west coast of Korea: Implications for compensation and recovery. Ocean \& Coastal Management 102, 533-544.

Kontovas, C.A., Psataftis, H.N., Ventikos, N.P., 2010. An empirical analysis of IOPCF oil cost data. Marine Pollution Bulletin 60, 1455-1466.

Lee, Y.G., Garza-Gomez, X., Lee, R.M., 2018. Ultimate costs of the Disaster: Seven Years After the Deepwater Horizon Oil Spill. The Journal of Corporate Accounting \& Finance, 29 (1), 69-79.

Liu, X., Wirtz, K.W., 2006. Total oil spill costs and compensations, Maritime Policy \& Management 33, 49-60.

Liu, X., Wirtz, K.W., 2009. The economy of oil spills: Direct and indirect costs as a function of spill size. Journal of Hazardous Materials 171 (2009) 471-477.

Loureiro, M.L., Ribas, A., L_opez, E., Ojea, E., 2006. Estimated costs and admissible claims linked to the Prestige oil spill. Ecol. Econ. 59 (1), 48-63.

Loureiro, M.L., Loomis, J.B., V_azquez, M.X., 2009. Economic valuation of environmental damages due to the prestige oil spill in Spain. Environ. Resour. Econ. 44 (4), 537-553.

Lu. L., Goerlandt, F., Valdez Banda, O.A., Kujala, P., Höglund, A., Arneborg, L., 2018. A Bayesian Network risk model for assessing oil spill recovery effectiveness in the ice-covered Northern Baltic Sea. Marine Pollution Bulletin, Volume 139, 440-458. 
Montewka, J., Weckström, M., Kujala, P., 2013. A probabilistic model estimating oil spill clean-up costs - A case study for the Gulf of Finland. Marine Pollution Bulletin 76, 61-71.

NOAA, 1999, Discounting and the Treatment of Uncertainty in Natural Resource Damage Assessment (Washington, DC: National Oceanic and Atmospheric Administration Damage Assessment and Restoration Program).

Oil \& Gas UK, OPOL, 2012. Oil spill cost study-OPOL financial limits.

Perry, R., 2010. Economic loss, punitive damages, and the Exxon Valdez litigation. Georg. Law Rev. 45, 409.

Rodgers Jr., W.H., Crosetto III, J., Holley, C., Kade, T., 2005. Exxon Valdez reopener: natural resources damage settlements and roads not taken. Alaska Law Rev. 22, 135.

Sabet, S.A.H., Cam, M.A., Heaney, R., 2012. Share market reaction to the BP oil spill and the US government moratorium on exploration. Australian Journal of Management 37(1) 6176.

Shahriari, M., Frost, A., 2008. Oil spill cleanup cost estimation-Developing a mathematical model for marine environment. Process Safety and Environmental Protection. 86(3), 189-197.

Thébaud, O., Bailly, D., Hay, J., Agundez, J.P., 2005. The cost of oil pollution at sea: an analysis of the process of damage valuation and compensation following oil spills. Economic, Social and Environmental Effects of the Prestige Oil Spill de Compostella, Santiago, pp. 187219.

Turner, R. K., Subak, S. E. and Adger, W. N., 1995, Pressure, trends and impacts in the coastal zone: interations between socio-economic and natural system, CSERDE working paper. 